\title{
Characteristics of the qualitative composition of soil organic matter: problems and solutions
}

\author{
Alexander Popov ${ }^{1 *}$, Georgy Kholostov $^{1}$, Ekaterina Sazanova ${ }^{1}, \mathrm{Julia}_{\text {Simonova }}{ }^{1}, \mathrm{Ksenia} \mathrm{Tsivka}^{2}$ \\ ${ }^{1}$ St.Petersburg State University, Russian Federation, 199178, St. Petersburg, 16th Line, H. 29, Soil Science and \\ Soil Ecology Department \\ ${ }^{2}$ St. Petersburg State Agrarian University, Russian Federation, 196600, St. Petersburg, Pushkin, Petersburg \\ Road, 2, Soil Science and Agrochemistry Department
}

*Corresponding author: Alexander Popov, e-mail: paihumic@gmail.com

\begin{abstract}
The components of soil organic matter (SOM) such as lipids (waxes, fats, and resins), pigments (oxyanthraquinones and related substances, tetrapyrrole compounds and carotenoids), kerogen, glomalins, and hydrophobins are briefly described in the paper. In the traditional assessment of the qualitative composition of SOM, all of the above substances, as well as the products of hydrolytic destruction of detritus and partially decomposed plant material, pass into the alkaline solution. The resulting mixture, containing both specific and individual organic compounds, is usually subdivided into fulvic acids, hematomelanic and humic acids. It is proposed to revise the methodology for extracting various components of SOM. The new method should be based on the affinity of the SOM components for certain organic solvents and should allow the separation of humic substances and melanin from glomalin and hydrophobins.
\end{abstract}

Keywords: soil organic matter, humic substances, melanin, lipids; pigments, glomalins, hydrophobins, kerogen; detritus, semi-decomposed plant residues

\section{Introduction}

Assessment of the state of natural objects is carried out on the basis of environmental monitoring, the most important part of which is a monitoring of soil, including soil organic matter (SOM). Academician V.R. Williams (1949) wrote that from whatever side we consider the soil, in terms of its origin, composition, physical and chemical properties and the processes occurring in it, whether we consider soil fertility or the content of nutrients in it, whether we discuss soil cultivation, fertilization, drainage or irrigation - the question of the soil organic matter as the main factor determining its entire character, properties, the entire physiology of the soil comes up everywhere.

Soil organic matter is a sophisticated complex of individual compounds and humic substances (HS), as well as products of their interaction and with the mineral part of the soil. It is a very dynamic complex and heterogeneous system, in which the components are interconnected and are represented in a certain established proportion (Popov and Chertov, 1996). The individual organic compounds are present in the soil in free form or in the composition of more complex substances of biogenic origin, but they are not included in HS (Orlov et al. 1996). One part of individual organic compounds is constituent parts of organisms that lived on/in the soil, as well as their excretions, and the other part is the transformation products of excreta and postmortal biota residues (Schnitzer, 1978). The chemical composition of organic residues of biota entering the soil is very diverse (Aleksandrova, 1980; Kononova, 1963; Orlov et al. 1996; Panikov et al. 1984; Flaig, 1971). 
Humic substances, as follows from the generalization of the scientific literature (Popov, 2004) are amorphous dark brown high molecular weight natural amphiphilic amphoteric organic nitrogencontaining redox heteropolymers, characterized by the absence of strict constancy of chemical composition. These specific compounds give the genetic horizons of soils, along with mineral compounds, a specific dark colour and determine a number of properties such as plasticity, resistance to penetration, viscosity, structure, ion exchange, biological activity, as well as heat-water-air, food, acid and salt regimes. By virtue of historically established traditions, the classification of HSs is based on their difference associated with the extraction of these specific compounds from natural objects by certain solvents, mostly alkaline solutions. According to Orlov et al. (1996), during extraction from the soil, along with HS, nonspecific compounds are also released, while further separation of HS probably leads to concomitant reactions (for example, hydrolysis of HS, inclusion of some lowmolecular compounds - degradation products - into molecules of high molecular weight biopolymers. Possible precursors of humic substances are melanins characterized as amorphous high molecular weight dark-colored pigments that are formed during the life of prokaryotes, including actinomycetes and fungi found in soils (Zvyagintsev and Mirchink, 1986; Lyakh and Ruban, 1972; Mishustin et al. 1956; Saiz-Gimenez and Martin, 1979). Melanins, being complex heteropolymers, differ both in the set of monomeric units and in the types of bonds (Lyakh and Ruban, 1972). The variety of starting monomers and the high activity of intermediate products make the chemical composition of melanins diverse and the structure of the polymer irregular (Britton, 1986).

High-molecular-weight specific and nonspecific components of SOM are gradually converted under the action of chemical reactions into low-molecular-weight (Flaig, 1971). Low molecular weight products of biochemical oxidative and hydrolytic degradation are a rapidly renewable (labile) organic material. Non-specific organic compounds of secondary origin can be found in the soil, in particular: phenolic compounds, amino acids, aliphatic acids, as well as oligo- and monosaccharides (including amino sugars and uronic acids) (Aleksandrova, 1980; Kononova, 1963; Orlov et al. 1996; Panikov et al. 1984; Flaig, 1971).

The purpose of this paper is to characterize such nonspecific organic compounds as lipids, kerogen, hydrophobins, and glomalins, based on the analysis of scientific literature. These substances have unique and multifunctional properties, which in the near future will allow them to be used for diagnostic purposes.

\section{Theoretical analysis of the topic}

In addition to HS, melanin, and low molecular weight organic compounds, the SOM contains: lipids (fats, waxes, resins, etc.), chlorophyll-like compounds and carotenoids, kerogen (polymeric organic substances, which are one of the forms of unconventional oil), hydrophobins (proteins formed by mushrooms) and glomalins (glycoproteins) (Aleksandrova, 1980; Kononova, 1963; Orlov et al. 1996; 
Panikov et al. 1984; Semenov and Kogut, 2015; Flaig, 1971; Nichols, 2003; Wright and Upadhyaya, 1998). Figure 1 shows the functional-genesis classification of SOM.

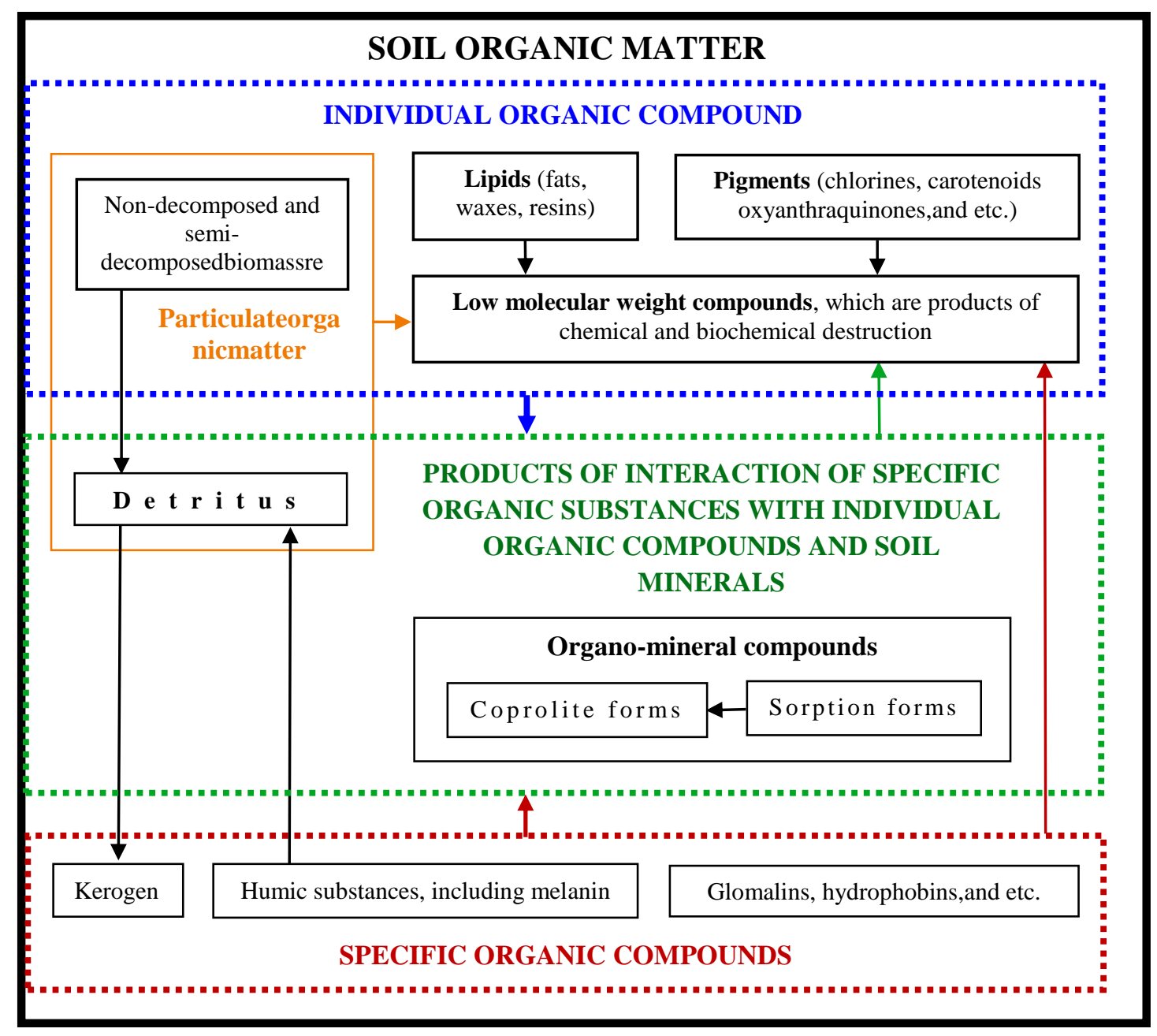

Figure1. Functional-genesis classification of soil organic matter

In practice, Russian soil scientists determine the qualitative composition of SOM according to the humus state (Grishina and Orlov, 1978; Orlov et al. 2004), which is based on the alkaline extraction and fractionation of humic acids (HA) and fulvic acids. According to other researchers (Lehmann and Kleber, 2015; Paul, 2016), the isolation of so-called "humic substances" by any alkaline solutions and their subsequent fractionation is not correct. In addition to HS and melanins, nonspecific organic compounds also pass into the alkaline extract: lipids, chlorophyll-like compounds and carotenoids, as well as kerogen, hydrophobins, and glomalins. In addition, in our opinion, as a result of hydrolytic destruction, detritus components and partially decomposed plant material also pass into the liquid phase of the alkaline solution (Fig. 2). That is, the existing system for assessing the qualitative composition of SOM is not satisfactory. 
Dispersed organic matter - the fraction of SOM ranging in size from 0.053 to $2 \mathrm{~mm}$ (Cambardella and Elliott, 1991) is isolated by sieving, includes partially decomposed soil detritus and plant material, pollen, etc. (Gregorich et al. 2006).

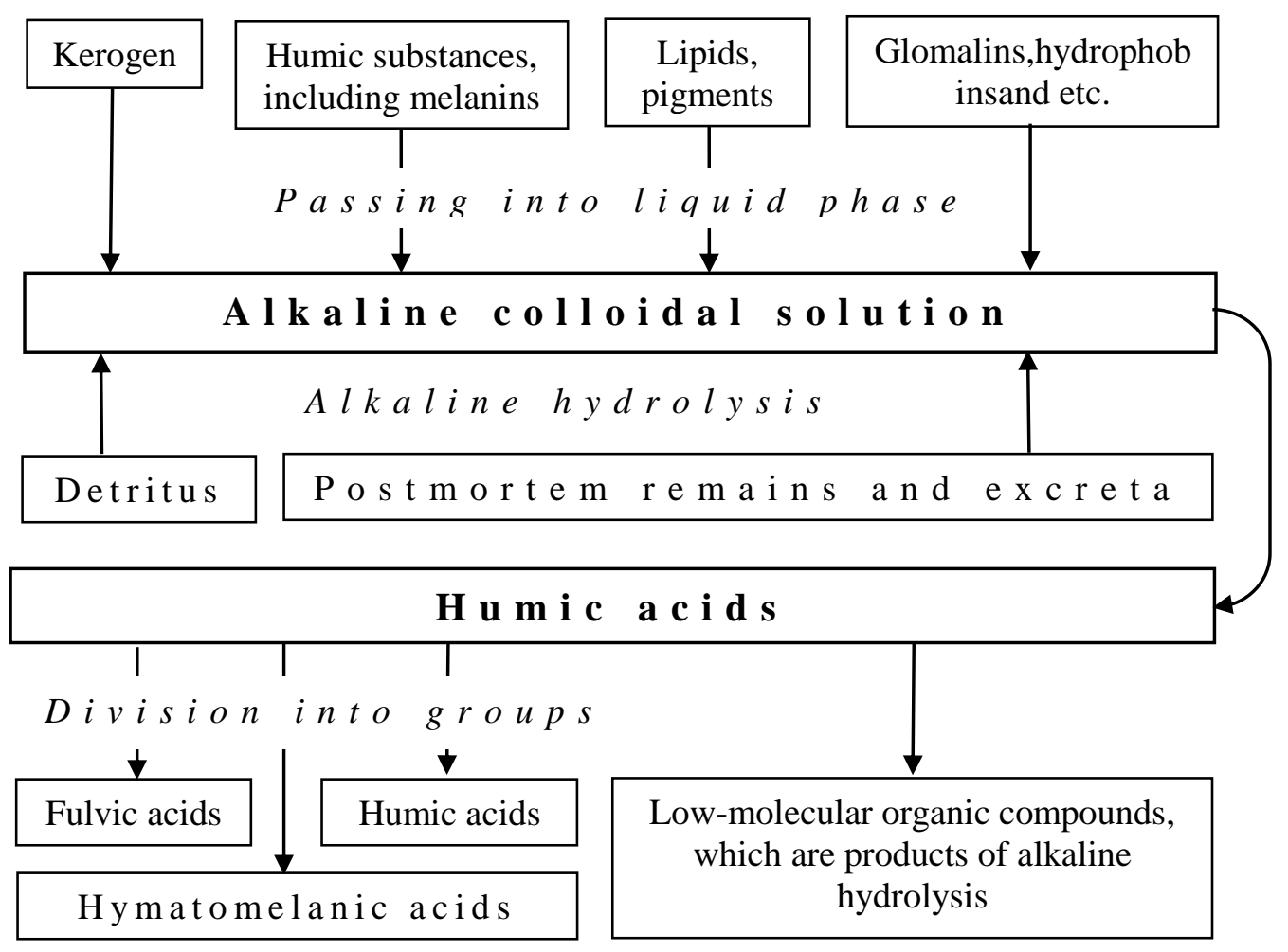

Figure2. Alkaline extraction of "humic acids"

Lipids are a large and varied group of natural compounds, united by a common property: their practical insolubility in water and good solubility in organic solvents. These compounds, depending on the ability to hydrolysis, are divided into saponifiable and unsaponifiable. Saponifiable lipids are divided into simple and complex. During hydrolysis, simple lipids form two components: alcohols and carboxylic acids, while complex lipids form three or more components. Simple lipids include waxes and fats, and complex lipids include phospholipids, glycolipids, and sphingolipids. Unsaponifiable lipids include steroids, fat-soluble vitamins, and prostaglandins (Slesarev, 2001).

Waxes are organic compounds formed by higher carboxylic acids and high molecular weight monohydric alcohols of various structures. Waxes contain about 300 different substances, among which esters, hydrocarbons, free fatty acids, aromatic substances, water, dyes, minerals and other substances predominate (Beryozov and Korovkin, 1998). The main constituent of waxes is esters (up to $75 \%$ ) formed by palmitic, neocerotinic and melissinic acids, ceryl and melissin alcohols. In addition, waxes contain cerotinic, montanic and oleic acids and neoceryl and montaninic alcohols. Cerotinic and melissic acids are the most active part of waxes; these acids can react with most metal cations, including alkali (http://biokhimija.ru/lekcii-po-biohimii/13-belki/56-glikoproteiny.html ) 
Fats are simple lipids that according to their chemical structure are esters of fatty acids and glycerol. All fatty acids in their composition contain a carboxyl group (so called the head of a fatty acid) and a radical (or a tail, which is hydrophobic). The differences between fatty acids are associated with the different structure of their radical. Fatty acids are divided into saturated fatty acids, the radical of which does not contain double bonds, and unsaturated fatty acids, which are characterized by the presence of double bonds in the radical (Beryozov and Korovkin, 1998). In addition to free fatty acids, their triglycerides, and waxes, the composition of soil lipids can also contain small amounts of other substances that enter the soil from living organisms. In addition, resin acids, pigments, etc. belong to soil lipids (Panikov et al. 1984).

Analysis of the fractional composition of lipids by thin-layer chromatography made it possible to reveal that hydrocarbons (in particular, squalene and alkoxyglycerides) absolutely predominated in the agro-gray soils of the Bryansk region. Triglycerides, sterols and their esters were detected in small amounts. First of all, as a result of biochemical decomposition, the content of polar, more reactive compounds (sterols, triglycerides and sterol esters) decreased in the lipid fraction.Changes in the composition of soil lipids and lipids of organic residues can serve as a marker of the intensity of transformation of organic matter. According to the data of gas-liquid chromatography, compounds with an even number of carbon atoms in the chain predominated among fatty acids. In this case, the selection of the most kinetically stable acids with the shortest chain length - myristic acid with fourteen and palmitic acid with sixteen carbon atoms - takes place (Kovaleva et al. 2005). Experiments on preparative column chromatography on silica gel showed that the lipids of the humus horizons of forest soils include low-polar (41-42\%) and high-polar (2-7\%) lipids, glycolipids (up to $60 \%$ in the Aeh horizon) and phospholipids (9-15\%) (Ziegler, 1989) [50]. The results of a field experiment (Wrightet al 1996) showed that over 87 weeks of observation, the lipid content gradually decreased, while the structural changes in the macromolecular parts of the soil lipids were small, and the part of the lipids firmly bound to the solid phase of the soil remained practically unchanged.

Pigments are a group of coloured soil biogenic substunces that pass into an alcohol-benzene extract, which include oxyanthraquinones and related substances, tetrapyrol compounds, carotenoids, and some others (Volnova and Mirchink, 1972; Panikov et al. 1984; Hoyt, 1971). Soils contain a certain amount of porphyrins and corrin compounds, which can be reversibly fixed and preserved without destruction, while chlorophylls belonging to SOM can act as an indicator of soil waterlogging (Kozyrev, 1991).

So, lipids are nonspecific compounds of SOM and are represented mainly by paraffins and resins. These are the most persistent compounds in soil and are slightly biodegradable. The high kinetic stability of lipids determines the relative stability of their content in natural soils, which has an important indicator value for the diagnosis of soil formation processes. 
Kerogen is all dispersed organic matter of any genetic type, syngenetic to the host rocks, representing an association of heterogeneous detrital and finely dispersed organic residues, transformed mostly under anaerobic conditions. It is a part of the dispersed organic matter of sedimentary rocks (low stages of transformation) that is insoluble in organic solvents but soluble in alkaline solutions (Bogorodskaya et al. 2005; http://www.mining-enc.ru/k/kerogen/). The most important feature of kerogen, which is a precursor of oil and combustible gases in the geosphere, is the uniqueness of its chemical structure. This is connected, firstly, with the different composition of the initial organic matter, secondly, with the different ratio of the contribution of the initial bioproduction to the geopolymer formation, and, thirdly, with the specific geochemical conditions in which the organic matter accumulated (Bushnev and Buredelnaya, 2010). Elemental composition of sapropel-type kerogen: $\mathrm{C}-64-93 ; \mathrm{H}-6-10 ; \mathrm{O}-0-25 ; \mathrm{N}-0.1-4.0 ; \mathrm{S}-0.1-8.0(\%)$, humus-sapropel type: $\mathrm{C}-64-$ 96; H - 1-5; O - 3-25; N - 0.1-2.0; S - 0.1-3.0 (\%) (http://www.mining-enc.ru/k/kerogen/). During the metamorphism, with an increase in the proportion of carbon, the proportion of hydrogen and heteroelements decreases. The structure of kerogen is presented in the form of a macromolecule composed of condensed carbocyclic nuclei connected by heteroatomic bonds or aliphatic chains (Bushnev and Buredelnaya, 2010).

Hydrophobins are small (7-9 kDa) amphiphilic proteins found exclusively in filamentous fungi and consisting of about $100 \pm 25$ amino acid residues. The structure of hydrophobins is represented by two structural domains, each of which contains four cysteine residues involved in the formation of intramolecular disulfide bridges. The degree of homology of amino acid residues between hydrophobins is low. Hydrophobins turned out to be a completely new class of proteins with peculiar physicochemical properties. Their isolation required the use of methods atypical for protein isolation. The abundance of hydrophobic amino acid residues and their connection with the cell wall of hyphae gave the name "hydrophobins" (Belozerskaya, 2001; Kolesnikov et al. 2014; Wessels, 1997).Hydrophobins contain both hydrophilic and hydrophobic amino acid residues, that is, they are amphiphiles. Therefore, hydrophobins are able to self-assemble into an amphipathic membrane at the interface between the hydrophobic and hydrophilic phases (Wösten and de Vocht, 2000).

A characteristic feature of hydrophobins is the presence of eight cysteine residues that form disulfide bridges (Wessels, 1994; Wessels, 1997; de Vries et al. 1993). Depending on the clustering of hydrophobic and hydrophilic regions, hydrophobins are divided into two classes (Kolesnikov et al. 2014). The membrane formed by class I hydrophobins has a very low solubility and can only be dissociated by highly concentrated acids (such as formic acid or pure trifluoroacetic acid). The complexes formed by class II hydrophobins are less stable and therefore can be easily dissolved in $60 \%$ ethanol or $2 \%$ sodium dodecyl sulfate solution (Kolesnikov et al. 2014; Wösten et al. 1993).

Glomalins are glycoproteins, complex organic hydrophobic compounds that are characterized by immunoreactive properties and the ability to bind iron. It has many features in common with other 
biomolecules, such as hydrophobins and HS (Nichols, 2003; Wright and Upadhyaya, 1998). The American soil scientist S. Wright (Wright et al. 1996) discovered and named soil glycoproteins as "glomalins", which were the metabolic product of arbuscular mycorrhizal fungi (AMF) of the order Glomales (GlomeralesL.), and the need to isolate these compounds from soils was justified by the microbiologist K.A. Nichols (Nichols, 2003).

From the standpoint of biochemistry (http://biokhimija.ru/lekcii-po-biohimii/13-belki/56glikoproteiny.html), glycoproteins, or more correctly, glycoconjugates, are proteins containing a carbohydrate component (glycan), which is covalently linked to a polypeptide substrate. Carbohydrates, as a rule, are attached to the protein either by an $\mathrm{N}$-glycosidic bond to the amide nitrogen of asparagine, or by an O-glycosidic bond to the hydroxy group of the serine, threonine andhydroxylysine residue. The proportion of carbohydrates in them varies from 15 to $20 \%$ by weight; does not contain uronic acids; the carbohydrate chains contain no more than 15 links, while carbohydrates have an irregular structure.

Glomalins in SOM are present in large quantities (as a rule, $2-15 \mathrm{mg} \mathrm{g}^{-1}$ and in some cases even up to $60 \mathrm{mg} \mathrm{g}^{-1}$ ) in various soils (both acidic and calcareous, and in soils of meadow and arable lands) (Wright and Upadhyaya, 1998). The high content of glomalins is mainly due to the abundance of AMF hyphae in the soil, the length of which can reach $100 \mathrm{~m} \mathrm{~cm}^{-3}$ (Miller et al. 1995) and the slow rate of destruction of this glycoprotein, from 7-42 to 100 years (Rillig, 2004; Steinberg and Rillig, 2003). The amount of glomalins in the soil can compose 1-5\% of the total carbon of soil organic matter, sinceglomalins contain 30-40\% carbon, 1-2\% nitrogen, and up to 5\% iron, which can give the soil a reddish color(http://www.agrocounsel.ru/rol-pochvennyh-gribov). The identification of glomalins synthesized by AMF led to an overestimation of the contribution of fungi to SOM and aggregate stability (Miller et al. 1995; Wright et al. 1996). As shown by the studies of Bedini et al. (2009), plant mycorrhization contributes to: an increase in the concentration of glomalins in the soil and the proportion of water-resistant aggregates with a diameter of 1-2 $\mathrm{mm}$. Glomalins surround microaggregates and glue them together to form macroaggregates and improve soil structure.

Usually, arable soils are dominated by prokaryotes that do not synthesize glomalins. Mechanical soil cultivation destroys macroaggregates, which leads to soil compaction. Compacted soils can create anaerobic conditions in which fungi do not thrive. On the other hand, soil cultivation increases the amount of oxygen in it, stimulating the growth of the bacterial community that uses polysaccharides and glomalins as a trophic substrate. In addition, a wide range of modern fungicides is toxic to the mycorrhizal population of fungi. Mechanical tillage, excess of mineral fertilizers and pesticides, short crop rotations and long fallow periods contribute to a decrease in the population of fungi, in particular AMF, and a decrease in the content of glomalins in the soil (http://www.agrocounsel.ru/rol-pochvennyh-gribov). In soils enriched with organic matter, the activity of soil fungi and microorganisms significantly increases (Chekmarev et al. 2011). The 
biological activity of most fungi is largely determined by biopolymers of a carbohydrate nature, the content of which can reach up to $50 \%$ of dry mortmass (Vetchinkina et al. 2008).

It should be noted that glomalins are usually released at a high temperature $\left(121^{\circ} \mathrm{F}\right)$ with a buffered solution (usually containing a chelator, most often citrate ion). Under these conditions, glomalins are very likely to change chemically. The extraction of glomalins reduces its immunoreactivity due to conformational changes and the presence of other substances, such as iron and citrate ion, which "bind" to glomalins and cannot be removed by chemical treatment. Hydrolysis and oxidation reactions are also possible under such extraction conditions (Nichols, 2003; Nichols and Wright, 2005).

It was found (Schindler et al. 2007) that a high carbon content of aromatic (42-49\%) and carboxyl (24-30\%) compounds in glomalins, as well as a low content of aliphatic compounds (4$11 \%$ ) and carbohydrate carbon (4-16\%), indicates that glomalindidn't resemble a typical glycoprotein. Moreover, the NMR spectra of glomalins strongly resembled the HA spectra. This implies that current methods for extracting glomalins, due to their similarity to the method used for extracting HA, facilitate the recovery of both materials. In addition, a common pattern was revealed between the synthesis of glycoconjugates and melanins: with an increase in the dark pigment in the mycelium, the amount of endoglycoproteins also increases (Vetchinkina et al. 2008).

Understanding the involvement of soil fungi and microorganisms in soil stabilization at the molecular level will lead to the development of ways to increase the resilience of agricultural systems (Wright and Upadhyaya, 1998). The unique properties and polyfunctionality of glycopolymers suggests that they can be used for diagnostic purposes of SOM (Popov and Sun Ge, 2017). However, there are currently a number of issues related to the study of glomalins. First, it is not yet possible to obtain "pure" glomalins with modern methods. Secondly, the exact chemical composition and the presence of functional groups have not yet been clarified. All these problems limit further research and the use of glomalin for diagnostic purposes.

\section{Conclusion}

In our opinion, the only solution to studying the qualitative composition of SOM is to develop a relatively simple and adequate analysis that allows separating HS and melanins from glomalins, hydrophobins, lipids and kerogen, as well as undecomposed and semi-decomposed plant and fungal residues. This, obviously, will be a method based on the affinity of the SOM components for certain organic solvents. And most importantly, it is necessary to revise the methodology for the extraction of HS and other SOM components.

Acknowledgement: This work was supported by the RFFI grant 19-29-05243. 


\section{References}

Aleksandrova LN. 1980. Organic substance of the soil and the processes of its transformation. Leningrad, Nauka, p 287

Bedini S, Pellegrino E, Avio L, Pellegrini S, Bazzoffi P, Argese E, Giovannetti M. 2009. Changes in soil aggregation and glomalin-related soil protein content as affected by the arbuscular mycorrhizal fungal species Glomus mosseae and Glomus intraradices.Soil Biology and Biochemistry 41(7):1491-1496.

Belozerskaya TA. 2001.Hydrophobins of fungi: structure and function. Mycology and phytopathology, 35(1):3-11

Beryozov TT, Korovkin BF. 1998. Biological Chemistry: Textbook 3rd ed., Overwork with additions, Moscow, Medicine, p 704

Bogorodskaya LI, Kontorovich AE, Larichev AI. 2005. Kerogen: methods of study, geochemical interpretation. Novosibirsk, SO Russian Academy of Sciences, "Geo" branch, p 254

Britton G. 1986. Biochemistry natural pigments. Moscow, Mir, p 422

Bushnev DA. Burdelnaya N.S. 2010.Chemical structure of kerogen.Herald of the Institute of Geology of the Komi Research Center of the Ural Branch of the Russian Academy of Sciences. 189(9):2

Cambardella CA, Elliott ET. 1991. Particulate soil organic-matter changes across a grassland cultivation sequence. SSSAJ 56(3):777-783 doi:10.2136/sssaj1992.03615995005600030017x.

Chekmarev PA, Lukin SV, Siskevich YI, Yumashev NP, Korchagin VI, Khizhnyakov AN. 2011. Monitoring of the content of organic matter in arable soils of the Central Chernozem Region.Achievements of Science and Technology of AIC. 9:23-26

De Vries OMH, Fekkes MP, Wösten HAB, Wessels JGH. 1993. Insoluble hydrophobin complexes in the walls of Schizophyllum commune and other filamentous fungi. Arch. Microbiol, 159:330335 .

Flaig W. 1971. Organic compounds in soil. Soil Science 111(1):19-33.

Gregorich EG, Beare MH, McKim UF et al. 2006.Chemical and biological characteristics of physically uncomplexed organic matter. SSSAJ 70(3):975-985. doi:10.2136/sssaj2005.0116.

Grishina LA, Orlov DS. 1978. Soil Humus Indicators System.Soil Science Problems.Soviet Soil Guides to the 6th International Congress in Canada.Nauka pp 42-47

Hoyt P. 1971.Fate of chlorophyll in soil. Soil Science, 111(1):49-53.

http://biokhimija.ru/lekcii-po-biohimii/13-belki/56-glikoproteiny.html

http://waxes.chat.ru/sis.html

http://www.agrocounsel.ru/rol-pochvennyh-gribov

http://www.mining-enc.ru/k/kerogen/

Kolesnikov BA, Larionov IV, Shamtsyan MM. 2014. Obtaining surface-active proteins from the deep culture of the fungus Trichoderma viride.Izvestia St. Petersburg State Technological University, 25:47-50

Kononova MM. 1963. Organic matter of soil, its nature, properties and methods of study. Moscow, Publishing house of the USSR Academy of Sciences, p 314

Kovaleva NO, Terentieva EV, Kovalev IV. 2005. Lipid fraction of soil humus as a source of paleopedicological information.Humic substances in the biosphere. In: Materials III All Russian Conference, St. Petersburg, pp 64-65

Kozyrev FN. 1991. Soil chlorophyll as an indicator of soil waterlogging. Reports of VASHNIL, 5:3033

Lehmann J, Kleber M. 2015. The contentious nature of soil organic matter. Nature, 528:60-68.

Lyakh SP, Ruban EL. 1972. Microbial melanins. Moscow: Nauka, p185 
Miller RM, Reinhardt DR, Jastrow JD. 1995. External hyphal production of vesicular-arbuscular mycorrhizal fungi in pasture and tallgrass prairie communities.Oecologia 103:17-23.

Mishustin EN, Dragunov SS, Pushinskaya OI. 1956. The role of microorganisms in the synthesis of humus compounds. Izvestiya AN SSSR. Biology series 6:83-94

Nichols KA. 2003. Characterization of glomalin, a glycoprotein produced by arbuscular mycorrhizal fungi. Doctoral Dissertation, p 285

Nichols KA, Wright SF. 2005. Comparison of gloialin and humic acid in eight native U.S. soils. Soil Science 170(12):985-997.

Orlov DS, Biryukov ON, Rosanova MS. 2004. Additional indicators of humus state of soils and their horizons. Pochvovedenie 8:918-926

Orlov DS, Biryukova ON, Sukhanova NI. 1996. Organic matter of soils of the Russian Federation. Moscow: Nauka, p 254

Panikov NS, Sadovnikova LK, Fridland EN. 1984. Non-specific compounds of soil humus. Moscow, Publishing House Moscow University, p144

Paul EA. 2016. The nature and dynamics of soil organic matter: Plant inputs, microbial transformations, and organic matter stabilization. Soil BiolBiochem 98:109-126.

Popov AI. 2004. Humic substances: properties, structure, education. Ed. E.I. Ermakova.SPb .: Publishing house of St. Petersburg. University, p 248

Popov AI, Chertov OG. 1996. Biogeocetotic role of organic matter of soils. Herald of St.-Peterburg State University, series 3- Biology, 2:88-97

Popov A.I., Sun Ge. 2017.Glomalin- a new characteristic of the state of agricultural soils? Agroecological Bulletin. Issue 8: International collection of works, Part 2. Voronezh: Voronezh GAU. Pp 51-56

Rillig MC. 2004. Arbuscular mycorrhizae, glomalin and soil quality. Can J Soil Sci. 84:355-363.

Saiz-Gimenez S, Martin F. 1979. Chemical structure of a humus-like pigment.Izvestiya AN SSSR, series Biology 1:59-64

Schindler FV, Mercer EJ, Rice JA. 2007. Chemical characteristics of glomalin-related soil protein (GRSP) extracted from soils of varying organic matter content. Soil BiolBiochem 39(1)320 329.

Schnitzer M. 1978. Humus Substances: Chemistry and Reactions. In: Soil Organic Matter, Eds. M. Schnitzer and S.U. Khan. Development of Soil Sci. No. 8. Ottawa, pp 1-64.

Semenov VM, Kogut BM. 2015. Soil organic matter. Moscow: GEOS, 2015.233 p.

Slesarev VI. 2001. Chemistry: Fundamentals of the Chemistry of the Living: Textbook for Universities / 2nd ed., St. Petersburg, Himizdat, p 784

Steinberg PD, Rillig MC. 2003. Differential decomposition of arbuscular mycorrhizal fungal hyphae and glomalin. Soil BiolBiochem 35:191-194.

Vetchinkina EP, Nikitina VE, Babitskaya VG, Scherba VV, Puchkova TA, Smirnov DA, Siege OV. 2008. Dynamics of the formation of glycoproteins and high-molecular phenols by the fungi Lentinusedodes under deep cultivation.Samarskaya Luka 17(2-24):367-372

Volnova AI, Mirchink TG. 1972. Formation of soil fungi pigment similar to the fraction of humic acid R-type.Herald of Moscow University. Series 6, Biology, Soil Science, 2:64-67

Wessels JGH. 1994. Developmental regulation of fungal cell wall formation.Annu. Rev. Phytopathol. 32:413-437.

Wessels JGH. 1997. Hydrophobins: proteins that change the nature of the fungal surface. Adv. Microbial Physiol. 38:1-45. doi: 10.1016/s0065-2911(08)60154-x.

Williams VR. 1949. Review of P.R. Slyozkin's dissertation "The Study of Humus". Collection of works in two volumes. T. 1. Moscow, Selhozgiz, pp 238-253 
Wösten HAB, de Vocht ML. 2000. Hydrophobins, the fungal coat unraveled. Biochim.Biophys.Acta 1469:79-86.

Wösten HAB., de Vries OMH., Wessels JGH. 1993. Interfacial selfassembly of a fungal hydrophobin into a hydrophobic rodlet layer. Plant Cell 5:1567-1574.

Wright SF, Franke-Snyder M, Morton JB., Upadhyaya A. 1996.Time-course study and partial characterization of a protein on hyphae of arbuscular mycorrhizal fungi during active colonization of roots. Plant Soil 181(2):193-203.

Wright SF, Upadhyaya A. 1998. A survey of soils for aggregate stability and glomalin, a glycoprotein produced by hyphae of arbuscular mycorrhizal fungi. Plant Soil 198(1):97-107.

Ziegler F. 1989. Changes of lipid content and lipid composition in forest humus layers derived from Norway spruce. Soil BiologBiochem 21(2):237-243.

Zvyagintsev DG, Mirchink TG. 1986. On the nature of humic acids of soils.Pochvovedenie 5:68-75 


\title{
Карактеристике квалитативног састава органске материје земљишта: Проблеми и решења
}

\author{
Alexander Popov ${ }^{1 *}$, Georgy Kholostov ${ }^{1}$, Ekaterina Sazanova $^{1}$, Julia Simonova $^{1}$, Ksenia Tsivka $^{2}$
}

${ }^{1}$ St.Petersburg State University, Russian Federation, 199178, St. Petersburg, $16^{\text {th }}$ Line, H. 29, Soil Science and Soil Ecology Department

${ }^{2}$ St. PetersburgStateAgrarianUniversity, Russian Federation, 196600, St. Petersburg, Pushkin, Petersburg Road, 2, Soil Science and Agrochemistry Department

*Corresponding author: Aleksandr Popov, e-mail: paihumic@gmail.com

\section{Извод}

У раду су укратко описане компоненте органске материје земљишта (OM3), као што су липиди (воскови, масти и смоле), пигменти (оксантракхинони и сроднесупстанце, тетраролинска једињења и каротеноиди), кероген, гломалини и хидрофобини. Код традиционалне процене квалитативног састава ОМЗ-а, све горе наведене супстанце, као и производи хидролитичке деструкције детритуса и делимично разграђеног биљног материјала, прелазе у алкални раствор. Добијена смеша, којасадржии специфична и појединачнаорганскаједињења, се обичнодели дели на фулвинске киселине, хематомеланске и хуминске киселине. Предлаже се ревизија методологије за екстракцију различитих компоненти ОМЗ-а. Нова метода треба да се заснива на афинитету компонената ОМЗ за одређена органска раствараче и треба да омогући раздвајање хуминских супстанци и меланина од гломалина и хидрофобина.

Кључне речи: органска материја земљишта, хумусне материје, меланин, липиди, пигменти, гломалини, хидрофобини, кероген, детритус, полу-разложени биљни остаци 